\title{
Jewish Liturgy During the Early Stages of the COVID-19 Pandemic: Vignettes from Boston Suburbs
}

\author{
Ruth Langer ${ }^{1}$ (D)
}

Received: 17 October 2020 / Accepted: 26 February 2021 / Published online: 15 June 2021

(C) The Author(s), under exclusive licence to Springer Nature B.V. 2021

\begin{abstract}
In March 2020, because of the COVID-19 pandemic, American synagogues locked their doors. This required emergency planning for Passover observances, and then gradually less panicked planning for subsequent liturgies. Based primarily on the experiences of three Boston-area synagogues, Reform, Conservative, and Orthodox, and interviews with their rabbis, this article compares the liturgical responses of Jews in these three movements, offering explanations for their different approaches. It also briefly traces, where appropriate, their resumption of services over the summer and their plans for the fall holy days.
\end{abstract}

Keywords Pandemic $\cdot$ COVID-19 $\cdot$ Liturgy $\cdot$ Worship $\cdot$ Synagogue $\cdot$ Minyan · Zoom $\cdot$ Passover $\cdot$ Pesach $\cdot$ Pesah $\cdot$ Shabbat $\cdot$ Sabbath $\cdot$ Rosh Hashanah $\cdot$ Yom Kippur $\cdot$ High Holy Days $\cdot$ Kaddish

$\begin{array}{ll}\text { Abbreviations } \\ \text { CCAR } & \text { Central Conference of American Rabbis } \\ \text { CJLS } & \text { Committee on Jewish Law and Standards } \\ \text { CST } & \text { Congregation Shaarei Tefillah } \\ \text { JTA } & \text { Jewish Telegraphic Agency } \\ \text { KI } & \text { Knesseth Israel } \\ \text { OH } & \text { Orah Hayyim } \\ \text { RA } & \text { Rabbinical Assembly } \\ \text { TBE } & \text { Temple Beth Elohim }\end{array}$

Ruth Langer

ruth.langer@bc.edu

1 Boston College, Chestnut Hill, MA, USA 


\section{Background}

COVID-19 appeared in Massachusetts in early March, 2020. The March 6 announcements of Newton's Congregation Shaarei Tefillah advised not touching fellow congregants or kissing the Torah. March 9-10, the synagogue held its Purim readings of Esther, but quickly, sitting a bit distanced, with a call-in audio option; it cancelled its community dinner. March 10, Massachusetts declared a state of emergency. March 11, as the World Health Organization (WHO) announced a global pandemic, my university, Boston College, ceased in-person instruction, and by March 13, all synagogues voluntarily locked their doors. The governor's closure of nonessential services on March 24 did not include religious institutions, but it did restrict any indoor gatherings to a maximum of ten people. Combining medical advice and Jewish values, though, rabbis prioritized any potential saving of lives and forbade even this (Appendix; Schachter March 15 2020). With Massachusetts being one of the states hit hard by the initial surge of the virus, the initial 2-week closure extended into the summer when it was lightened but not fully removed. Consequently, the pandemic affected daily and Sabbath services as well as Passover, Shavuot 7 weeks later, and between them, the modern observances of Holocaust Memorial Day, Israeli Independence Day and Jerusalem Day. The rabbis whom I interviewed (during a lull in the pandemic in June) all anticipated that they would be unable safely to resume "normal" liturgies until we are vaccinated, meaning that they correctly anticipated reshaped fall holiday liturgies too.

Only in mid-June, as the state began reopening, did the first local synagogues initiate in-person outdoor services for a limited number of registered, masked, socially distanced attendees. As of late July, Massachusetts infection rates were among the lowest in the United States, but were beginning to creep up again slightly; numbers in the United States had already gained the dubious distinction of being among the worst globally. This essay took its shape in midsummer 2020, and it has been lightly updated since, especially with some data on High Holy Day services. Patterns set in the first months of the pandemic, however, informed subsequent liturgical choices in the communities studied. Thus, while written in the midst of an evolving history, its study of these early patterns of response stands on its own.

A comprehensive study, even within this period, is beyond the scope of an article. Instead, I focus on three west-suburban Boston synagogues and interviews in June 2020 with their rabbis: Congregation Shaarei Tefillah (CST, Newton, modern Orthodox, Rabbi Benjamin J. Samuels) ${ }^{1}$; Congregation Kehillath Israel (KI, Brookline, Conservative, Rabbi William Hamilton) ${ }^{2}$; and Temple Beth Elohim (TBE, Wellesley, Reform, Rabbi Joel Sisenwine). ${ }^{3}$ In the footnotes, I reference alternative choices evident from the recorded services available via the websites, YouTube channels or Facebook pages of a number of additional synagogues, mostly but not all from

\footnotetext{
1 My active affiliation. https://www.shaarei.org/. Interview June 18, 2020.

2 https://kehillathisrael.org/. Interview June 19, 2020.

3 https://tbewellesley.org/. Interview June 23, 2020.
} 
this same geographic area. All the synagogues included are affiliated with the larger organized American movements.

\section{The Meta-Issues}

What factors drove the liturgical choices made by these three congregations when faced with this sudden massive disruption to their central communal function as a place for gathering for worship? In America, Jewish authority rests ultimately in individual synagogue's lay leadership, but functionally, for the questions addressed here, decisions were led by the clergy they chose to hire. These clergy themselves turned to their networks. Whom they in turn consulted and the nature of the authority structures embedded in those relationships also shaped the decisions made. One of the factors that distinguishes the three movements represented by these three synagogues is their relationship to traditional halachah and the authority they understand it to embody. Understandings of two halachic issues primarily determined synagogues' liturgical directions: whether virtual services constitute public prayer, and whether technology may be used on Sabbaths and holidays.

Traditionally, Judaism requires the presence of a minyan (quorum) for all public prayer (m. Meg. 4:3). This determines whether one may proclaim Scripture (vs. studying it) and whether certain particularly holy prayers may be recited, the most emotionally sensitive being the mourner's kaddish. Orthodox synagogues require an in-person minyan of ten adult male Jews. Gatherings including women and children must be larger. Virtual services are thus technically private prayer. Conservative synagogues all permit remotely joining an in-person (egalitarian) minyan, but they debate whether the quorum may be fully virtual (CJLS March 17 2020), affecting the service's contents. Reform synagogues generally accept the validity of a virtual (egalitarian) minyan, at least in this time of emergency (CCAR Responsa 2012; CCAR Responsa 2020; CCAR March 12 2020). Thus, the parameters of a community's possible liturgical response to the pandemic are shaped first and foremost by its understanding of "minyan."

A community's understanding of Sabbath and festival laws further delimits possibilities for virtual liturgies on these high-stakes days. Orthodox Jews do not use communications technology, instrumental music or adjust electrical devices on these days, except for reasons of health. Therefore, a virtual service or attendance at one is possible only on the lesser attended (but halachically equally important) weekdays. Most Reform Jews freely use electricity, technology and musical instruments any time and do not consider themselves bound by received halachah. Some already broadcasted their services. Conservative synagogues reflect a range of practices between these two extremes, with robust, though not universal, support for a careful use of Zoom services (Heller 2020). ${ }^{4}$ These factors set the ritual context for communal Jewish liturgical life during the pandemic.

\footnotetext{
${ }^{4}$ See also the various supporting and dissenting rulings posted with it (CJLS Orah Hayyim, s.v. Shabbat).
} 


\section{Case Studies}

\section{Orthodox}

Orthodox CST has 250 families, the majority of whom weekly attended at least part of a Sabbath or holiday morning service before the pandemic. The congregation presumes that all pray and study the lectionary privately, even when not attending public services. Texts are provided. Through the spring and summer, some gathered on Zoom before the Sabbath to hear brief words from the rabbi and the pre-Sabbath part of the Friday night service led by a member. Saturday night after dark, the congregation also offered the brief home liturgy (havdalah) marking the return to weekday time. While initially attended by as many as 75 screens, these dropped off significantly over time. Festival liturgies reduce these elements, so no equivalents were offered. On weekdays, the congregation offered synchronous individual prayer over Zoom, including, as need emerged, multiple morning services. As the congregation cautiously resumed small, outdoor services over the summer, Zoom connections to weekday services continued for those precluded from attending. All the congregation's other weekday activities continued via Zoom, including a Thursday evening stand-in for the Saturday morning sermon, when a congregant offered an "Interactive D'var Torah."

The authority for liturgical decisions (in consultation with the ritual committee and the board) rests ultimately with the synagogue's rabbi (its sole clergy), but he himself networks with the local, national, and international rabbinic worlds. A few voices have emerged as especially influential in their abilities to apply halachic precedents to this modern pandemic. Among Americans, two (of many) rulings by Rabbi Herschel Schachter particularly shaped pandemic liturgical decisions. ${ }^{5}$

Rabbi Schachter ruled that a minyan requires close physical proximity and hence virtual services constitute parallel private prayer (March 31 2020; Reisman, 15-21). Thus, they must omit key elements, including the kaddish customarily recited by mourners. Anticipating this, Rabbi Samuels immediately circulated on March 13 a substitute text appropriate for private recitation. ${ }^{6}$ On March 17, he instituted a Zoom afternoon/evening service ${ }^{7}$ so mourners could find community and fulfill the psychological and social functions of kaddish recitation. Gradually, morning services were added as well. Not all find this satisfying, but many do, and some other synagogues have imitated it (Winberg 2020). Those unable to attend the small outdoor services in person this summer because of health concerns must still rely on this solution, even when "attending" virtually. As Rabbi Samuels told me, in many ways, in the short term, Orthodoxy's halachically responsible decisions fail its constituents liturgically, but he believes that in the long term, it will preserve a tightly knit, physically proximate community.

\footnotetext{
5 See also: Orthodox Union Guidance Regarding Coronavirus (2020).

6 From Nirenberg (1993), 35, a prayer book developed for an inter-congregational women's prayer group in Montreal.

7 With a short learning session separating them in memory of the deceased.
} 
Holidays presented other challenges. While Passover week includes four days ${ }^{8}$ of festival liturgies plus the Sabbath, its unique focus is the family-oriented seder meals on the first two nights. The pandemic eliminated holiday travel and home hospitality, leaving many totally alone. There was much discussion about Zoom seders. Determinative in forbidding them for most was Rabbi Schachter's ruling that, while exceptions could be made if loneliness or illness threatened one's life, use of electronic communications on the holiday was not permitted. ${ }^{9}$ Rabbi Samuels asked congregants facing such challenges to discuss their situations with him privately, taking seriously possible threats to mental health.

The seder liturgy incorporates elaborate food rituals as well as a feast. Rabbi Samuels arranged that a catered "Seder in a Box," each containing a multi-course meal for two in addition to the ritual foods, be supplied to all who requested it, underwritten by a congregant. ${ }^{10}$ In this, he supported a local caterer, enabled stressed congregants to greatly simplify their Passover preparations, and enabled a fulfilling (and filling) seder for many, focused on the liturgy. ${ }^{11}$ Passover was not normal, but anecdotal evidence suggested that many found it meaningful.

Shavuot presented in many ways a larger challenge, as its focus is communal reception of the Torah. Many participate in all-night vigils, studying together, concluding at dawn with the morning service and reliving Sinai by reading Exodus 19-20. Many fewer stayed up; studying the Torah portion lacked the drama of the communal reading from a scroll. CST studied together over Zoom in the days preceding the holiday, including celebrating a communal completion of the entire Pentateuch. Other communities handled this ritual learning differently. My daughter's community in Chicago completed their communal reading on the festival and participated in a neighborhood inter-synagogal virtual study session when the holiday ended Saturday night. The night before the holiday, CST gathered on Zoom for a combined reading of Ruth and memorial prayers, both normally read on the festival's second day. Yizkor, recited four times a year, combines communal and personal memories of the departed and prayers for their afterlife. That spring's renditions added a memorial for COVID-19 victims. It could have simply been recited privately on the festival, but the communal gathering was emotionally needed, now as during Passover.

Lifecycle rituals have also been affected as all are built around communal gatherings. Normally, effecting a marriage requires a minyan to recite the Seven Wedding Benedictions. Rabbi Schachter ruled that because such a gathering was dangerous, weddings require only a truncated liturgy with two witnesses and the officiant

\footnotetext{
8 Two in Israel.

9 On the controversy including an English translation of the widely rejected lenient ruling that began it, see Dunner (2020). See also Schachter (March 25 2020).

${ }^{10}$ Lipman (2020). This became a city-wide project of the Combined Jewish Philanthropies, though often with just the ritual necessities for the evening.

11 Rabbanit Leah Sarna, my daughter, was one of the imitators. Her congregation included many younger adults who had always traveled "home" for the holiday. Their kitchens were thus unequipped for Passover, and they had never managed the festival's complex details; Rabbanit Sarna compiled "The Minimalist's Guide to Passover and the Seder," also widely imitated (2020).
} 
physically present (April 2 2020). Circumcision requires only the baby, a parent, and the trained circumciser, truncating the celebration but not the rite. My grandson's circumcision and naming took place at his home, with close family joining by Zoom. A few days later, his parents named him publicly via a Zoom webinar attended by hundreds from around the world; others held analogous ceremonies for daughters. Bar and bat mitzvahs for Orthodox young adults have been held via Zoom, but not on the Sabbath. None of these included their customary parties, although several have integrated party-like elements like dance music or quiz-show elements in addition to more serious speeches. Finally, funerals have been graveside with attendance restricted according to state and cemetery rules. Rabbi Samuels has facilitated postburial memorial services on Zoom that, like a funeral, often include recitation of Psalms and eulogies, especially by the mourners. Many, after the funeral, during their week of formal mourning (shiva), have held visitation hours over Zoom (and by late summer, outdoors). However, they were not able to hold shiva services in their homes, but have, if desired, joined the synagogue's daily Zoom synchronous prayers (or later, the outdoor minyan).

Thus, Orthodox liturgical options were very much limited by our two halachic considerations. The complete cessation of communal prayer generated significant tension across the Orthodox world. This led CST, guided by a team of doctors, to a careful institution of in-person services under an awning during the later summer, limited to 12 men to ensure a minyan, plus up to 12 women. Improved pandemic numbers in the fall enabled doubling these numbers. The congregation offered abbreviated outdoor fall holiday services simultaneously in multiple locations and shifts, attended by hundreds. Snow eventually forced the removal of the awning, and cold drove all but one 10-minute daily evening service indoors, again with reduced numbers permitted and many reluctant to attend. ${ }^{12}$

\section{Conservative}

Because their parameters for the use of electricity and hence technology on the Sabbath are very different, Conservative and Reform Jews have had many more liturgical options. Rabbis Hamilton and Sisenwine both hold services via Zoom and have designed them to maximize a sense of community and connection. Both report significantly larger attendance than normal. ${ }^{13}$

The Conservative Movement had already confronted the issue of virtual participation in a minyan, providing the groundwork for an easy pivot (Reisner 2001). ${ }^{14}$ The Committee on Jewish Law and Standards (CJLS) of the Rabbinical Assembly

\footnotetext{
${ }^{12}$ Rabbi Schachter continues to issue guidance. For his collected rulings related to the pandemic, including for the High Holy Days, see Rav Herschel Schachter on Special Topics.

${ }^{13}$ This is apparently the case elsewhere as well, but requires proper study. For now, see Cohen (2020) about Detroit, Hartog (2020) about Los Angeles, and the possibilities created by the website jewishlive.org.

${ }^{14}$ Building on this permission to fulfill prayer obligations in exigent circumstances by voice connection with a physical minyan, Rabbi Joshua Heller was preparing a discussion of Zoom services for the CJLS when the pandemic struck (Heller 2020).
} 
provides halachic leadership to the Conservative Movement. However, the CJLS often issues both majority and minority opinions; individual rabbis may legitimately choose a minority opinion as operative for their congregation or simply go their own way. Thus, local Conservative synagogues have approached our questions with different nuances, though all offer some or all services virtually with clergy officiating alone, many from their sanctuaries. ${ }^{15}$ Their cameras are set before the Sabbath and remain on for the day; congregants are encouraged to do the same. As of mid-July, few were meeting in person, even outdoors, in spite of limited gatherings being now legal in Massachusetts. ${ }^{16}$

Conservative liturgies are substantially traditional, and local synagogues preserved that during the pandemic. The Rabbinical Assembly provided pdfs of their prayer books to congregations, and KI, which uses its own text, mailed copies to all its members. While some Conservative synagogues include most or all elements requiring a minyan in these virtual services, Rabbi Hamilton did not. He sought to mark that this is not a normal, ideal service, while simultaneously meeting the social and emotional needs of his congregants. That meta-concern, rather than strict halachic considerations, drove his decisions. Thus, Torah study replaced Torah reading, but creatively. On Saturday morning, seven congregants each discussed a part of the lectionary; Saturday afternoon, he summarized the reading. ${ }^{17}$ Only when there was a bar or bat mitzvah did he take out the Torah scroll. The child, who with family joined Rabbi Hamilton in the sanctuary, read from the scroll but with blessings for Torah study, not proclamation. Other small liturgical omissions were likely minimally disruptive to congregants, as the prayer leader recited private prayers aloud, creating opportunities for others to respond "amen" as they would normally.

The mourner's kaddish is the only prayer he included that requires a minyan. When Zoom services began, he tried substituting an English translation with recitation of biblical verses appropriate to individuals being remembered. This did not meet the emotional needs of the mourners. Although the words of kaddish do not directly address mourning, the performance of this Aramaic praise of God at all services daily for 11 months and thereafter on the anniversary of the death is the final obligation one owes to parents and near relatives. Reliving the spiritual meaning

\footnotetext{
${ }^{15}$ Few record Sabbath services because this verges on writing, violating Sabbath rest. Rabbi Hamilton followed a ruling that transient images on a screen fall into a different halachic category. See Computer on Shabbat.

16 The single exception locally in July seemed to be Temple Emanuel, Newton Centre (https://www. templeemanuel.com/), which just moved its Tuesday and Friday evening services outdoors and welcomed a limited number of congregants within marked family circles on the lawn. The services were livestreamed from there. By September, KI was also offering outdoor services twice a week.

17 Compare this to Temple Reyim, Auburndale (http://www.reyim.org/), which livestreams Saturday morning (its only non-interactive virtual service). The rabbi, with the help of his wife and son, takes out the Torah and chants part of the weekly portion from the scroll. His service includes all prayers requiring a minyan except the Torah reading's blessing marks it as study. Temple Emanuel, Newton Centre, livestreams Sabbath services. Friday night three socially distanced clergy provided instrumental music and harmonies from the sanctuary (or later in the summer, their garden with a small congregation). Saturday morning their livestream is managed, with the camera shifting angles and the screen highlighting congregants at home taking on various liturgical roles. The aesthetic level of each service is very different. Both congregations livestream through StreamSpot, which records and posts recent events.
} 
he found in reciting kaddish for his mother, Rabbi Hamilton was unable to dismiss the needs of current mourners. Discussion with Rabbi Benny Lau (Israel) led him to a realization that, although halachah is important, other religious considerations were also relevant, especially in an emergency situation and in regard to matters of such spiritual intimacy. This exception also applied to the Yizkor memorial services on festivals. Then, uniquely, Rabbi Hamilton utilized a screen share-here arranged in advance and managed by a non-Jew, as halachah prohibits a Jew's adjusting the computer in any way.

Excluded are as much as a quarter of his community who are not halachically or technologically comfortable with Zoom services, especially on Sabbaths and holidays. For the High Holy Days, the congregation offered a full menu of services via Zoom, but also ensured an in-person minyan in the sanctuary, inviting congregants to sign up for short blocks. This full liturgy was live-streamed over Zoom. They also ran some limited outdoor in-person services. The congregation continued this pattern in following months for the Sabbath morning and weekdays when the Torah is read. Rabbi Hamilton has found the support offered from the Conservative Movement of limited value in shaping his decisions.

Rabbi Hamilton found Zoom opened opportunities for holiday observances. Families, even those normally separated, could gather for seder. KI offered seders both nights, the first night more traditional, in pre- and post-meal segments, and the second night a shorter version of the entire haggadah in one segment, paying attention "to emotional expressiveness to respond to emotional rawness of moment" (cf. Hamilton 2020). He titled his Shavuot learning experiences, "Covid Demands Meet Sinai Commands," dedicating each to a separate commandment. These ranged from events in the days leading up to the festival, some of which, like a "sermon slam," normally are part of a large inter-congregational learning festival first night, to more formal sermons. However, those interested in learning online on the festival itself outside of services were expected to take advantage of the wealth of opportunities provided by others.

\section{Reform}

Most Reform congregations do not understand Sabbath commands to limit their choices; many had embraced technology already, whether for livestreaming services, projecting prayers and images, or replacing paper with tablets. However, officially, the movement had still required an in-person community for prayer. This was set aside as a temporary emergency ruling as long as "there are ten people connected in an interactive manner," meaning that Zoom services are appropriate, but fully prerecorded or webinar-style services showing only the speaker are not (CCAR Responsa Committee 2020). It is very difficult to assess the degree to which this guidance is followed, as generally only the livestreams via Facebook or congregational websites are available to guests, most recorded in "speaker view." 18

\footnotetext{
18 There are literally hundreds of synagogues livestreaming their services. JewishLIVE (https://www. jewishlive.org/services) aggregates the links and makes recommendations.
} 
A March 31 communication from the entire leadership of the Movement urged congregations "to take the most restrictive steps possible," offering as their only in-person function graveside funerals with everything else virtual, and encouraging clergy to lead services from their own homes (Reform Jewish Movement's, March 31 2020). This apparently became the norm initially; some clergy began to broadcast from their empty sanctuaries this summer, especially because this enabled multiple voices and instrumentation to blend without the time lag that creates cacophonies on live Zoom. As states moved to reopen in the summer, the Reform Movement (together with the other major non-Orthodox movements) issued guidelines for assessing resuming in-person services, still urging great caution (Working Group 2020). Synagogues remained closed for the fall holy days (or a small group gathered in person, with the rest on Zoom).

The Reform Movement provided exceptional professional support for brainstorming, planning, and networking, with a rich array of webinars encouraging clergy to plan ahead creatively for the fall holy days. ${ }^{19}$ These discussions were also responsive to the gradually emerging understanding about aerosol transmission of the virus, especially through singing or shofar blowing. TBE in mid-July resumed holding small, socially distanced, outdoor Saturday night havdalah services, but all else remained on Zoom. Its only in-person High Holy Day observances were family-oriented outdoor gatherings to blow shofar and for havdalah on Yom Kippur.

The primary variation in Reform liturgical choices seems to be around whether to transfer a normal liturgy to Zoom (the majority) or to craft a more creative virtual gathering. Rabbi Sisenwine initially generated a "Shabbat Experience," creating community around a virtual Sabbath table, but this gradually transformed to an experience shaped around a more conventional synagogue-oriented liturgical structure. His service retained the touchpoints of Reform liturgy; it was anchored by well-known Hebrew responses and songs, without most of the interconnecting paragraphs. Congregants were not initially expected to have prayer books, but by the fall, the congregation provided links to free e-resources as well as opportunities to purchase books to enable more liturgy. In early summer, the service included a few texts shared on screen, including a new prayer for caregivers and COVID sufferers, ${ }^{20}$ but for the most part, participation was based on memory. Kaddish was the only prayer that normally requires a minyan. However, issues of minyan were not a common concern, according to my non-scientific sampling of recorded services from other Reform congregations.

Participation is key. After a shared screen or spotlight has bumped Zoom into "speaker view," Rabbi Sisenwine reminds everyone to return to gallery view so that they may see their friends. His congregants are not missing liturgy, he says; they are missing community. They do not feel obligated to pray the set liturgy as do more traditional Jews; they do feel obligated to each other. He encourages active engagement by inviting congregants to use the chat, in general, but also to share names of people

\footnotetext{
19 A disclaimer: I have access to their internal materials, but rely on the reports of my sources for conclusions about other movements.

${ }^{20}$ In hashkiveinu, the prayer asking for divine protection.
} 
for whom they recite kaddish or those in need of healing prayers. ${ }^{21}$ Rabbi Sisenwine also instituted sharing people's "sacred moments of the week," birthdays, anniversaries, retirements, or other milestones mostly emailed to him in advance. He does preach, providing some intellectual content. Indeed, in June, he reported about triple his normal in-person attendance for this and all virtual programs.

Zoom creates challenges in addition to opportunities, especially because it does not easily handle multiple simultaneous audio sources. With multiple rabbis and cantors, plus screen sharing, a tech person becomes necessary; even so, all participants must be muted except one. Consequently, when we spoke, Rabbi Sisenwine was beginning to experiment with leading services occasionally from a congregantfree sanctuary with multiple clergy socially distanced there. He also occasionally inserted prerecorded music. As he noted, the explosion of musical creativity in Reform liturgy has led to a dependence on platforms that enable it. ${ }^{22}$

As of our interview, for the then upcoming fall holidays, the "high stakes" season for Jewish liturgy, he was considering mixing recorded and live segments. This would provide some protection in case technology crashed. It also answers the problem of "Zoom fatigue." These services are substantially longer than online attention spans, so his various segments required separate sign-ons and built-in breaks. Rabbi Sisenwine voiced substantial disagreement with the provocative suggestion of Dr. Lawrence A. Hoffman (2020), one of the Reform Movement's leading liturgists and teachers, who suggested abbreviating these services by: radically re-envisioning the liturgy around a relevant theme; analyzing what actually works today; and eliminating all else. The spring holidays, comparatively, were "low stakes." TBE offered a communal seder the first night and paired up families the second night of Passover, providing everyone with a haggadah text, complete with links to commentaries and music. Shavuot has long been the time of Confirmation, marking the completion of religious education. Like most other Covid-era graduations, it happened over Zoom. The extended study sessions of the day took advantage of Zoom also, connecting with speakers in Israel.

TBE represents only one version of the many models for virtual services in the Reform Movement. Variables that emerged include: whether clergy are in their homes, just like the congregants, or broadcasting from the otherwise empty synagogue with its more sophisticated technology; whether segments or sometimes all of the service is prerecorded, enabling editing together segments created in a variety of venues and with media not always possible in the physical synagogue; and, of course, choices made about the contents and patterns of the liturgy itself, with or without texts shared on the screen, sometimes taking up the screen and confining the officiant to a Zoom box, and sometimes side by side with a full-sized live camera view. All of these opened up creative possibilities.

\footnotetext{
${ }^{21}$ Traditionally recited in conjunction with Torah readings, but Reform synagogues have for decades transformed this into a self-standing and expected liturgical element.

22 For an extreme comparison, Temple Israel in West Bloomfield, Michigan, with the aid of a congregant in the business, generated some entirely prerecorded and edited services for special events June 26 and July 3 (recordings on Facebook). The recordings took advantage of multiple locations, including the sanctuary.
} 


\section{Conclusions}

Historically, when plagues struck, Jews gathered for penitential prayers $(\mathrm{OH} 576: 2$, 12; Ne'етпи M'od (2020), 122-137). Scientific understanding of the transmission of disease has significantly changed this: although some dedicated prayer gatherings were convened virtually, ${ }^{23}$ they were mostly not penitential. Although prayer still has power, more Jews pray for the scientific researchers and first responders, and for healing the ill, than for miraculous divine intervention. However, an oral instruction from Rabbi Schachter, followed by CST, did encourage weekday recitation of the penitential prayer, Avinu Malkeinu (Our Father our King), which includes a plea for God to prevent and remove plague.

However, as this essay has demonstrated, the possibilities for public prayer during the pandemic have been shaped by a community's location on the spectrum of halachic understanding, especially regarding the requirements for a minyan and the permissibility of using technology on Sabbaths and holy days. This has meant that the Orthodox world, normally the most liturgically intense, has been the least successful in praying together through the pandemic. While small in-person minyanim have gathered, these necessarily exclude many who would normally attend, either because of size restrictions or because of an individual's health concerns. A normally strong community is fragmented without other means of coming together for Sabbath and festival prayer. The Reform world has seized the moment, sometimes with vast creativity and an enhancement of their community. The Conservative world, not a locus for substantial liturgical creativity, has, though, sometimes carefully leveraged technology to enhance the power of prayer in community. In all cases, it seems likely that these new experiences of virtual prayer will leave permanent marks on how Jews gather before God.

\section{Appendix: Open-Letter from Boston-Area Orthodox Rabbis to Our Communities $^{24}$}

\section{Adar, 5780 - March 13, 2020}

Dear friends,

We write to you this erev Shabbat with ahavat Yisrael (the love and concern for every individual Jew in our community), kavod haberiyot (the dignity of every human being), and an aspiration toward responsible leadership. Our incredibly interconnected world faces a serious threat of pandemic (novel coronavirus, COVID-19), and many of us may feel legitimately anxious. One of the

\footnotetext{
23 For example, the Orthodox Union instituted a daily virtual gathering to recite Psalms combined with rabbinic words of support from March 13 until mid-July 2020. See https://www.ou.org/callarchive/. It continues with more targeted Psalm recitation (https://www.ou.org/tehillim-chizuk/) [both accessed July $31,2020]$. However, these are not penitential prayers; nor do they include recitation of passages about incense offering, traditionally part of such plague liturgies because the biblical Aaron offered incense to halt a plague (Num 17:11-13). See Orthodox Union Guidance Regarding Coronavirus.

24 As circulated by Congregation Shaarei Tefillah in its March 13 announcements.
} 


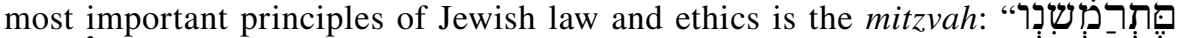

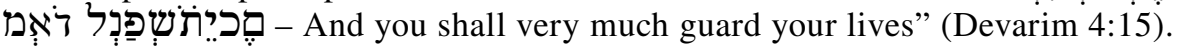
We have a fundamental religious duty to protect our own health and safety, as well as that of others. This mandate overrides every other mitzvat aseh (affirmative Torah and Rabbinic obligations). Keeping safe and not causing harm are Biblical Mitzvot of the highest proportions, while praying with the congregation and hearing the leining is a Rabbinic Mitzvah. Our Sages say (TB Yoma 85b) that it is better to minimize one Shabbos in order to have the health to celebrate future Shabbatot; " טהב יחר - and you shall live by them (Vayikra 18:5)," and not imperil yourselves through the mitzvot. We have continued to be in contact with medical and public health professionals, as well as poskim and Jewish leaders nationwide, to develop guidelines for Shabbat, and ongoing during this public health crisis, that honor this call to action.

Based on a best-practice approach (notably the Rabbinical Council of Bergen County), effective Friday, March 13th at 3 pm, we are taking the below precautionary steps to mitigate health risks in our congregation and in the larger community. We will review and update this policy on a regular basis, as the situation continues to evolve:

1. We are suspending all in-person Shul activities and closing our buildings to the public - including all minyanim, educational classes, meetings \& youth groups until further notice. People who need to pick up personal effects and religious items should do so this Friday, if possible. To continue to daven as a "Tzibbur" we recommend davening in your homes at standard Shul davening times, so we know that our tefilot will take place at the same time as the rest of our community, even if not in the same place. Read the parasha in keeping with our keriyat haTorah cycle. We will explore using technology to connect us during weekday davening times, even if a virtual minyan is not halachically possible.

2. We ask that our members NOT attend other minyanim in Shuls to which they do not belong, and NOT form private minyanim in households. This will undermine our communal effort to stop the spread of coronavirus. All of the Rabbis will be davening alone at their homes.

3. Life-cycle Events: We will not host public celebrations for the time being, but will work with families to find creative, safe ways to celebrate their simchas.

4. In the event of a funeral, God forbid, we may ask, depending on the circumstances at the time, that attendance be restricted to a small group of family members and a minyan. We will employ technology to share hespedim and honor the deceased and comfort the mourners. As such, shivah visits should be conducted by telephone or video calls.

5. While our local Mikvaot remain open, women under quarantine or who are experiencing symptoms of acute infectious illness (e.g., cold, flu, stomach bug) may not use the mikvah. Please direct any questions to your Rabbi, and/or Yoetzet Halachah ... and/or call your mikvah. 


\section{Positive Opportunities for Building and Sustaining Community}

The halachic and human dimensions of this present hour require us to separate physically, but also challenge us to bridge the "social distance" in other ways. We are called upon by our mesorah (Jewish tradition) to create social connections through small and large acts of chesed (caring and kindness). Each sub-community should make lists of people to call and check-in on, especially people who live alone or are at risk. Every physical step away from another human being must be replaced by a virtual step forward in terms of friendly connection and emotional support via the blessings of technology. Creativity is our bridge over "social distancing" and bring us together in our avodas Hashem, and keep people in the mode of soulful tefillah, shoring up their emunah, and feeling that they are not only protecting themselves and their families, and contributing to a local, regional, national and global response to pandemic, but that they are fulfilling the Torah's charge of "vaChai Bahem - And you shall live by them!".

This unprecedented health crisis presents us as a larger Jewish community, as particular Shuls, and as individuals with the challenge of growing religiously and spiritually through virtual limmud Torah, synchronized and/or livecast davening, Tehillim recitation, and singing, and acts of chesed. Our path ahead is not known at present, but [we] are confident that with Hashem's help, with our devotion, dedication and commitment to Torah, Mitzvot, Klal Yisrael, and human solidarity, we will overcome, persevere, and emerge stronger!

We wish everyone a Shabbat of spirit and strength. With tefillot to Hashem for health and hatzalah,

Rabbi Joseph Polak, Av Beit Din of the Boston Beit Din (Vaad HaRabbonim).

Rabbi Moshe M. Liberow, Menahel of the Boston Beit Din

Rabbi Noah Cheses, Young Israel of Sharon, Sharon, MA

Rabbi Mark Glass, Adams Street Synagogue, Newton, MA

Rabbi Yonatan Gorin, Congregation Etz Chaim, Sharon, MA

Rabbi David Hellman, Young Israel of Brookline, MA

Rabbi Yaakov Jaffe, Maimonides Kehillah, Brookline, MA

Rabbi Moshe Lieberman, Chabad of Newton Centre, MA

Rabbi Benjamin J. Samuels, Cong. Shaarei Tefillah, Newton, MA

Rabbi Gershon Segal, Cong. Beth El-Atereth Israel, Newton, MA

Rabbi Jason Strauss, Cong. Kadimah-Toras Moshe, Brighton, MA

Signatories as of Erev Shabbat, Friday, March 13, 10 AM

\section{References}

CCAR. March 12, 2020. "Central Conference of American Rabbis Responds to the Covid-19 Pandemic." https://www.ccarnet.org/the-central-conference-of-american-rabbis-covid19-pandemic-statement/. Accessed June 29, 2020.

CCAR Responsa Committee. 2012. A Minyan via the Internet? (5772.1). https://www.ccarnet.org/ccarresponsa/minyan-via-internet/. Accessed June 29, 2020. 
CCAR Responsa Committee. 2020. Virtual Minyan in Time of COVID-19 Emergency (5780.2). https:// www.ccarnet.org/ccar-responsa/5780-2/. Accessed June 29, 2020.

CJLS. Jewish Law, Orah Hayyim. https://www.rabbinicalassembly.org/jewish-law/committee-jewish-lawand-standards/wrh-hyym-orah-hayyim\#shabbat. Accessed September 25, 2020.

CJLS guidance for remote minyanim in a time of COVID-19. March 17, 2020. https://www.rabbinical assembly.org/story/cjls-guidance-remote-minyanim-time-covid-19. Accessed June 25, 2020.

Cohen, Shari. August 6, 2020. "The Future of Shul: How Declining Memberships and COVID-19 Could Change the Way We Worship," The Jewish News. https://thejewishnews.com/2020/08/06/the-futureof-shul-how-declining-memberships-and-covid-19-could-change-the-way-we-worship/. Accessed February 3, 2021.

Computer on Shabbat. Zomet. https://www.zomet.org.il/eng/?CategoryID=253\&ArticleID=318. Accessed July 15, 2020.

Dunner, Pini. April 2, 2020. The Zoom Seder controversy. https://rabbidunner.com/the-zoom-seder-contr oversy. Accessed July 12, 2020.

Hamilton, William. April 7, 2020. Spiritual dexterity: Lessons from Seder washing. Times of Israel. https://blogs.timesofisrael.com/spiritual-dexterity-lessons-from-seder-washing/. Accessed July 15, 2020.

Hartog, Kelly. November 13, 2020. “Whither brick-and-mortar synagogues in the US?” Jerusalem Post: 17. https://www.pressreader.com/israel/jerusalem-post/20201113/281908775674964. Accessed February 3, 2021.

Heller, Joshua. May 13, 2020. Streaming services on Shabbat and Yom Tov, OH 340:3.2020a. CJLS, Rabbinical Assembly. https://www.rabbinicalassembly.org/sites/default/files/2020-05/Streaming\% 20on\%20Shabbat\%20and\%20Yom\%20Tov\%20Heller.pdf. Accessed June 18, 2020.

Hoffman, Larry and Jackie Mates-Muchin. June 3, 2020. Re-envisioning High Holy Day liturgy - where do we begin? (webinar). https://www.ccarnet.org/event/re-envisioning-high-holy-day-liturgy-wheredo-we-begin/?sd=1591142400. Accessed June 30, 2020.

Lipman, Steve. Summer 2020. A pandemic of kindness. Jewish Action. https://jewishaction.com/opini on/a-pandemic-of-kindness/. Accessed July 29, 2020.

Ne'emnu M'od: Orekh Yamim. 2020 (5780). Edited by Yaakov Yehoshua Buksbaum. Israel: Mekhon Yerushalayim.

Nirenberg, Barbara. 1993. Siddur siftei Hannah. Montreal.

Orthodox Union Guidance Regarding Coronavirus. 2020. Orthodox Union. https://www.ou.org/covid19/. Accessed March 17, 2021.

Rav Herschel Schachter on Special Topics: Piskei Halacha on Coronavirus Shaylas. TorahWeb.org. https://www.torahweb.org/author/rsch_dt_special.html. Accessed September 26, 2020.

Reform Jewish Movement's recommendations on Covid-19. March 31, 2020. Central Conference of American Rabbis. https://www.ccarnet.org/reform-jewish-movements-recommendations-on-covid19/. Accessed June 29, 2020.

Reisman, Yisroel. December, 2020. “A Collection of Responsa Regarding Coronovirus.” Journal of Halachah and Contemporary Society LXXV: 15-33.

Reisner, Avram Israel. March 13, 2001. Wired to the Kadosh Baruch Hu: Minyan via internet. CJLS OH 55.15.2001. https://www.rabbinicalassembly.org/sites/default/files/public/halakhah/teshuvot/19912 000/reisner_internetminyan.pdf. Accessed June 29, 2020.

Sarna, Leah. March 30, 2020. The minimalist's guide to Passover and the Seder. https://docs.google.com/ document/d/188NcDqRa69qxvGmZwuSrwfh4yIR58McKuI9EggIgAAM/edit. Accessed July 20, 2020.

Schachter, Hershel. March 15, 2020. Psak halachah from HoRav Hershel Schachter shlit"a. TorahWeb. org. http://www.torahweb.org/torah/docs/rsch/RavSchachter-with-doctors_Mar-15-2020.pdf. Accessed June 18, 2020.

Schachter, Hershel. March 25, 2020, 29 Adar 5780. Sick person alone [Heb.]. https://images.shulcloud. com/1349/uploads/RavSchachter-Corona-2.pdf. Accessed July 12, 2020.

Schachter, Hershel. March 31, 2020. Joining a Minyan [Heb.]. TorahWeb.org. https://www.torahweb.org/ torah/docs/rsch/RavSchachter-Corona-8-Mar-31-2020.pdf. Accessed June 18, 2020.

Schachter, Hershel. April 2, 2020. A Wedding with Less than Ten [Heb.]. TorahWeb.org. https://www. torahweb.org/torah/docs/rsch/RavSchachter-Corona-13-April-02-2020.pdf. Accessed July 20, 2020.

Winberg, Rabbi Seth. March 25, 2020. You don't need Zoom or Skype to say Kaddish without a minyan. Here's a healthier option for the community. JTA. https://www.jta.org/2020/03/25/opinion/ 
you-dont-need-zoom-or-skype-to-say-kaddish-without-a-minyan-heres-a-healthier-option-for-thecommunity. Accessed July 12, 2020.

Working Group of the Reform, Conservative, and Reconstructionist Movements. June 19, 2020. Guide to the considerations about re-opening synagogue buildings. Version 1 . https://10pzbn347s7w1b9 a412ijnxn-wpengine.netdna-ssl.com/wp-content/uploads/2020/06/Cross-movement-reopeningresources-for-synagogue.pdf.Accessed June 29, 2020.

Publisher's Note Springer Nature remains neutral with regard to jurisdictional claims in published maps and institutional affiliations.

Ruth Langer is Professor of Jewish Studies in the Comparative Theology Area of the Theology Department at Boston College and Interim Director of its Center for Christian-Jewish Learning. She publishes widely in the areas of Jewish Liturgy and Christian-Jewish Relations. 